TITLE:

\title{
Evaluation of myocardial infarct size in rat heart by pinhole SPECT( Abstract_要旨)
}

AUTHOR(S):

Hirai, Taku

CITATION:

Hirai, Taku. Evaluation of myocardial infarct size in rat heart by pinhole SPECT. 京都大学, 2000, 博士(医学)

ISSUE DATE:

2000-03-23

URL:

http://hdl.handle.net/2433/180846

RIGHT: 
氏名平并篗

学位(専攻分野) 博士（医 学）

学位記番号医 博 第 2212 号

学位授与の日付 平 成 12 年 3 月 23 日

学位授与の要件学 位 規 則第 4 条第 1 項該 当

研究科・尃攻。医学研究科内科系専攻

学位論文題目 Evaluation of myocardial infarct size in rat heart by pinhole SPECT

（ピンホール型 SPECT 装置を用いたラット心臓における梗塞サイズの評価）

論文調査委員教授 中尾一和教授米田正始教授篠山重威

\section{論 文 内容 の 要 旨}

（背景）近年, 心臟核医学の領域においても, ${ }^{123} \mathrm{I}$-BMIIPP (iodine- 123-p-iodophenyl-3- (R, S) -methylpentadecanoic acid）や ${ }^{123}$ I-MIBG（iodine-123-metaiodo-benzylguanidine）などの新しいトレーサーが開発され，様々な臨床研究がな されてきた。しかし，これらの基礎的実験は非常に少なく，動物疾病モデルを用いた基礎的実験による解明が望まれている。 この動物モデルとしては犬などの大型動物が用いられることが多いが，このような系では（1）疾病モデルの作成に，専門施 設, 熟練した複数のスタッフを必要とし，（2）動物の購入，管理にコストがかかり，（3）慢性期の疾病モデルの作成が難し い,などの制約がある。

一方，ラットなどの小型動物は，小規模の実験施設，簡便な手術手技によって容易に疾病モデルを作成でき，また安価に 購入，管理ができる。このため，小動物モデルを用いた実験系の開発が核医学領域においても強く望まれている。近年， pinhole 型 single photon emission computed tomography（以下, pinhole SPECT）が小動物を用いた実験目的に開発さ れ，各種心疾患の経時的，非侵裝的評価が可能となった。しかしながら，現在までに正常例での検討はなされてきたが，実 際の疾病モデルを用いた基礎的報告はない。

（目的）当研究の目的は, ラット心筋梗塞モデルを用いて，慢性期の心筋 SPECT 像と組織標本から得られた所見とを比較 検討し, pinhole SPECT の小動物への応用の可能性について実験的に検討することである。

（方法）Wistar Kyoto Rat（ $\mathrm{n}=12 ）$ の左冠動脈を結禁し，実験的心筋梗塞を作成した。手術直前と 24 日後に，約 $74 \mathrm{MBq}$ の thallium-201 を大腿静脈より静注し, 10 分後より pinhole SPECT を撮像した。SPECT 短軸像の連続 $8 \sim 10$ 切片より, 全心筋サイズに対する梗塞サイズ (血流欠損部) の比率を算出し, SPECT 画像より求めた梗塞サイズ (\%SI) とした。また, 短軸像と長軸矢状断像を 20 セグメントに分け, 各セグメントを $0:$ normal, 1 : slightly decreased, $2:$ moderately decreased, 3 : no uptake とスコア化し，その総計を defect score（DS）として算出した。撮影終了後，ラット心臓を摘出し，ホ ルマリン固定後, 房室間溝に垂直に心室を心尖部から心基部まで 3 切片に切り分け, 合計 3 個の組織標本 (マッソントリク 口ム染色）を作成した。これから, 左室心内膜側の全周径に対する梗塞部径の比率を算出し, 組織標本より求めた梗塞サイ ズ (\%HI) とした。

(結果) 手術直前の SPECT 画像では，全てのラットで評価可能な正常イメージを示した。一方，24日後には左冠動脈の支 配領域に一致して欠損像が出現した。\%HI と\%SI は有意に相関を示し $(\mathrm{r}=0.97, \mathrm{p}<0.05)$ ，また\%HI は DS とも良い相関 を示した（r=0.74, $\mathrm{p}<0.05)$ 。

(考察) pinhole SPECT から算出した心筋梗塞サイズは組織像と非常によい相関を示した。これまでにも autoradiography のような実験手法を用いた基整実験は報告されているが，これらは摘出心筋を必要とし，非侵襲的かつ経時的評価が困 難であった。今回のこの pinhole SPECT を用いることにより，各種疾病モデルの非侵襲的かつ連続的な心筋代謝と血流の 評価が可能となり，各種トレーサーを用いた実験系に新たな展望を開くすのと考えられる。 


\section{論 文窨查の結 果の 要旨}

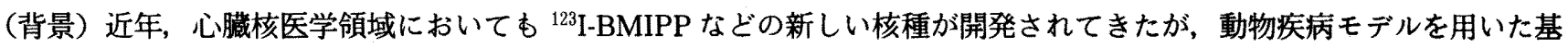
礎的実験は少なく，特に小動物による実験系の開発が望まれる。Pinhole SPECT は小動物用に開発したが, 垁病モデルを用 いた基礎的な報告はない。

（目的）Pinhole SPECT の画像評価を行い，さらにラット心筋梗塞モデルの SPECT 画像と組織像を比較検討し，小動物 への非侵襲的利用の可能性を検討した。

(方法) Wistar Kyoto Rat に左冠動脈結紫を行い，実験的心筋梗塞を作成した。手術直前と 24 日後に ${ }^{201} \mathrm{Tl}-\mathrm{SPECT}$ を撮像 し，24 日目の SPECT 像より梗塞サイズ（\%SI）を算出した。撮影後，心臓を摘出し，MT 染色標本を作成し組織学的に梗 塞サイズ (\%HI) を求めた。

(結果) 手術直前には, 全ラットで心 SPECT 像は正常イメージを示したが, 24 日後には左冠動脈支配領域に一致して欠損 像を認め, 高品位の心筋イメージが得られた。また\%HI と\%SI は有意な相関を示した（r=0.97, p<0.05)。

(考察) Pinhole SPECT により高解像度のラット心筋イメージが得られ, 心筋梗塞に伴う筋血流变化を経時的かつ明瞭に 評価できた。

以上の研究は，これまでは困難であった疾病モデルの非侵䃞的・連続的な心筋代謝・血流評価の可能性を示し，今後の実 験系に新たな展望を開くあのと考えられる。

したがって，本論文は博士（医学）の学位論文として価値あるあのと認められる。

なお，本学位授与申請者は，平成 12 年 2 月 4 日実施の論文内容とそれに関連した試問を受け，合格と認められたものであ る。 